\title{
Shan (Goodness) and Revolution
}

\author{
Masaru YAMADA
}

\begin{abstract}
In local societies of Sichuan, charities lead by local leaders were prevalent in the late Qing Period, right before the 1911 Revolution. The idea behind these charities was that the world was facing a fatal crisis for too many misdeeds committed by human beings, and the only way to rectify them and save the world was to accumulate good deeds. Some local elites who played leading roles during the 1911 Revolution in the Sichuan local societies were trying to establish what they believe was the desirable order in these local societies. In other words, we can confirm cases in which traditional thought prompted local elites to initiate revolution.
\end{abstract}

\section{Keywords}

The 1911 Revolution, Local Societies in Sichuan Province, Local Elites, Charities, Traditional Thought

\section{Introduction}

It might seem strange to suggest that local societies in Sichuan in the late Qing Period, right before the 1911 Revolution, was marked by a prominent belief in shan (good). However, countless cases of contributions to charities by local elites in the area can be found in the biographies of local chronicles. Also, Fuji (planchette writing) societies, which held activities to obtain shan guidance through spiritualism similar to table turning, were not rare. As I have discussed in previous research, people devoted themselves to shan because they believed that the world was facing a fatal crisis of jie (too many misdeeds committed by human beings); the only way to save individuals and the world from jie was to 
accumulate good deeds. ${ }^{1}$ Against this backdrop, concrete forms of ideal shan were presented to people through oracles based on Fuji, and charitable organizations were created to act on and promote the guidance of God to save themselves and the world.

This world view is not always clearly depicted in Chinese history after the 1911 Revolution. The activities of Fuji societies and the shan books they published were attacked by intellectuals of the new age after the Republic of China was established, and shan came to be judged as an outdated superstition. As I have explained in previous research, one of the best known examples of such criticism is Lu Xun's essay, "Suiganlu," which severely criticized the activities of Fuji societies and labeled their shan books as "superstitious" and "irresponsible rumors." 2 Lu Xun and other intellectuals who expressed opinions in China's New Youth felt that the ancient morals preached by Fuji societies were social ills symbolizing the old superstitious China.

Was this criticism also present in local societies? If a new age of enlightenment, where old superstitions are replaced by logical reasoning, had come with the new societies created following the 1911 Revolution, the extermination of old values and "shan books" should also have been observed in local societies. However, historical materials present an orientation toward shan based on the traditional framework of thoughts as well as efforts to realize shan in societies. If this is the case, it is necessary to revisit the prevailing pathos and ethic in local societies, as well as local trends before and after the 1911 Revolution. Moreover, this should be done from a perspective other than that of modern history as defined by Lu Xun or "progressive" urban intellectuals.

The seemingly outdated, superstitious, yet rigorous worldview of shan and salvation, which prevailed in Sichuan local societies in the late Qing Period was not fragile enough to be perished by social changes before and after the 1911 Revolution. Moreover, the "new" society after the 1911 Revolution and the worldview of the "old" Fuji and shan books were not in direct contrast with each other. Rather, an apparent "old" worldview, which continued to influence the formation and order of local societies, might have discretely affect changes in modern Chinese society.

This article reframes the craze for shan that prevailed in local societies in the late Qing Period, mainly societies in eastern Sichuan Province, from the

\footnotetext{
${ }^{1}$ Masaru Yamada, "Kiokusareru 'Chiiki': Ding Zhitan 'Shiinsai Shohitsu' no Sekai" [Remembered "Territory": The World of Ding Zhitan's "Shi Yin Zhai She Bi"], Toyoshi Kenkyu 62, no. 2 (2003). Masaru Yamada, "Kakumei Ideorogii no Tooi Suimyaku-Shinmatsu no 'Kyuko' Shiso wo Megutte" [Water Vein of the Ideology of Revolution: About the Philosophy of Saving "Jie" at the End of the Qing Dynasty], Chugoku-Shakaito Bunka 26 (2011).

2 Yamada, "Kakumei Ideorogii no Toori Suimyaku."
} 
perspective of its relation with social changes in modern China before and after the 1911 Revolution. ${ }^{3}$

\section{People Who Practice Shan - Sketch of Sichuan Local Society}

Some historical chronicles written in Sichuan in the late Qing Period severely criticize the concept of shan in traditional society. One example is a local chronicle called Fucheng Qixin, which was compiled in Fuzhou, Sichuan in the late Qing Period. "Local chronicles" in this sense are historical books that give concise accounts of local histories, which are used as texts for primary education and should be learned as the foundation of local autonomy. Lesson 33 of Fucheng Qixin, "Prevalence of the Liaofan School," and Lesson 35, "Sorceries of Writings and Guidance by Fuji Could Cause Unrest," describe the "Liaofan School," which represents the prevalence of Gongguoge (ledgers of merit and demerit), shan books including Taishan Ganyingpian and Wenchang Dijun Yinzhiwen and morals based on Fuji as follows:

Lesson 33: Prevalence of the Liaofan School

The Liaofan School is now prevalent in Fuzhou. Although its primary purpose is to promote the good and correct the bad ... wealth and longevity are determined by fate and are already recorded in the ledger by the master who dictates the destiny of people even before we are born. However, if one cultivates virtue he can change the predetermined fate: one supposed to die early can live long, and one supposed to be poor can be rich. Good and bad deeds should be recorded in the ledger everyday .... Also, they revere and recommend Ganyingpian and Yinzhiwen, which represent their school and

\footnotetext{
${ }^{3}$ Masao Nishikawa, Shisen no Kyoson Shakai: Shingaikakumei Zengo [Sichuan's Village Societies: Before and After the Xinhai Revolution] (2008) includes very detailed experimental studies of the region. However, it does not discuss the political culture and mentality of grassroots societies. A series of studies by Koetsu Fujiya should be noted when it comes to local societies, mainly in Hunan, before and after the Xinhai Revolution. See Koetsu Fujiya, "1906 Nen no Ping Liuli Houki to Minshu Bunka: Chuushusetsu no Yougen wo Chushinni” [Popular Culture and the Ping Liuli Uprising in 1906: On Popular Songs of Zhongxiujie], Shigaku Zasshi 113, no. 10 (2004). Koetsu Fujiya, "Shingaikakumei no Shinsei: Konansho no Minshu Bunka wo Chushin ni" [Mentality of the Xinhai Revolution: On Popular Culture in Hunan Province], in Chukasekai to Kindai (Series 20 Seiki Chugokushi 1), ed. Wataru Iijima, Tooru Kubo, and Yujiro Murata (University of Tokyo Press, 2009).

${ }^{4}$ As for Xiangzhenzhi and Xiangtuzhi, see Hitoshi Sato, "Kindai Chugoku no Chihoshi ni Miru Kyodoishiki: Konan Chiho wo Chushinni" [Village Identity Observed in Local Chronicles of Modern China: Mainly in Jiangnan Province], Shicho 56 (2004).
} 
preach that people can escape jie and gain happiness as long as they follow these teachings .... Even in the face of emergency, they merely say, "I can get away from jie because I am a good person. This propensity to shan is the mind Chinese people should hold instead of struggling to deal with the reality." This will surely cause great harm.

Lesson 35: Sorceries of Writings and Guidance by Fuji Could Cause Unrest

Everybody, no matter if he is a wise man or a fool, believes the writings and guidance given through the sorceries of Fuji. Intelligent people know that these are wrong inside, yet they do not totally reject them because they preach loyalty and piety and rationalize that their teachings are by those who died for loyalty during ancient times and have been worshipped. However, those people do not understand that a levee can be breached by a hole made by ants .... In our state, this custom was most popular in the Xianfeng Tongzhi period, but now they are not as popular as before.

Unlike many local chronicles complied in Sichuan around the same time, the purpose of Fucheng Qixin was, as represented in the title ( $q i$ means enlightenment and xin means new), to enlighten elementary learners in primary education with new knowledge appropriate to the new age. Therefore, it needed to exclude and attack old superstitious customs as seeds of disaster, just as Lu Xun had done.

However, the fact that Fucheng Qixin uncompromisingly attacked traditional shan books and spiritualism proves that they were indispensable and deeply penetrated within the local societies. In fact, the Liaofan School and related shan books were prevalent, and Fuji was popular during the Xianfeng Tongzhi Period at the end of the Qing Dynasty, and its embers were still burning. ${ }^{5}$

Many local chronicles compiled from the late Qing Period to the establishment of the Republic of China do not cast any doubt on the values and norms of shan, which, unlike Fucheng Qixin, were widely spread in society. Therefore, it is possible to get a sense of the social norms shared by people from other local chronicles that did not directly discuss these issues. It is not rare to encounter narratives that praise the lives of people who used Gongguoge, Ganyinpian, and Yinzhiwen as their guidance in local chronicles compiled in the late Qing Period and at the beginning of the Republic of China. Here are some examples.

\footnotetext{
${ }^{5}$ As for Sichuan society at the end of the Qing Dynasty and folk religion, see Masaru Yamada, Ijumin no Chitsuo: Shindai Shisen Chiikishakaishi Kenkyu [Order of Immigrants: Studies on Sichuan Local Societies during the Qing Dynasty] (University of Nagoya Press, 1995). Fusaji Takeuchi, "Shinmatsu Shisen no Shukyo Undo: Furan, Senkogata Shukyo Kesshano Tanjo" [Religious Movements in Sichuan in the Late Qing Dynasty: Foundations of Fuji and Xuanjiang Style Religious Associations], Gakushuin Daigaku Bungakubu Kenkyu Nenpo 37 (1994).
} 
Wu Qihong ... was a person of integrity with a sense filial duty and brotherhood. After his mother died young, he served for his mother-in-law for several decades as if it was only one day .... He was calm inside and friendly with others, and always disciplined himself by making Gongguoge. ${ }^{6}$

Zhang Deshen ... was from Laili Gulouchang .... He lectured about the essence of books such as Ganyingpian, Yinzhiwen, and Zhuzixiaoxue as an academic. He taught the lessons by example, saying that "you can't call yourself a person with high morals if you don't live by it. Even if you pass a higher civil service examination and get a bureaucratic position, it would not bring benefits in terms of public morals and the human mind." He taught Gongguoge of Yan Liaofan to older students with an academic foundation .... In his last years, he kept "public shan" in his mind, and started Shiquanhui in Gulouchang to support people in poverty. $^{7}$

Liang Quankai ... encountered Limingpian by Yan Liaofan while studying and started practicing shan devoutly .... He taught school at his house in his middleage ... having older students read Zhuzi Xiaoxue and younger students read Sanshengjing (three holy chants, including Taishang Ganyingpian, Wenchang Dijun Yinzhiwen, and Guangsheng Dijun Jueshijing). ${ }^{8}$

Cha Shunbang ... preached to people by sharing examples of obtaining good luck as a result of following the teachings of Ganyingpian and Yinzhiwen in xuanjiang (sermons). Many people started practicing shan after hearing his sermons .... He started Shiquanhui in Shilongchang to raise funds for benevolence, including the provision of medicine, coffins, and yizhong (public cemeteries). ${ }^{9}$

Although these are just a few examples, it is possible to draw some conclusions from the passages. First, Gongguoge and shan books, including Gangyingpian, Yingzhiwen, and Jueshijing were widely read in local societies, and those who used them for moral standards and taught others to do the same were admired. ${ }^{10}$

\footnotetext{
${ }^{6}$ Guangxu, Jintang Xian Xiangtuzhi [Jintang Prefecture Local Chronicle], Volume II, Qijiulu.

7 The Republic of China, Hechuanxianzhi [Hechuan Prefecture Local Chronicle], Volume 46, Xiangxian.

${ }^{8}$ The Republic of China, Hechuanxianzhi [Hechuan Prefecture Local Chronicle], Volume 45, Xiangxian.

${ }^{9}$ The Republic of China, Hechuanxianzhi [Hechuan Prefecture Local Chronicle], Volume 48, Xiangxian.

${ }^{10}$ Many studies on shan books are available. See Tadao Sakai, "Chugoku Zensho no Kenkyu" [Studies on Chinese Shan Books], in the Collection of Sakai, Tadao Works, Volumes I and II
} 
Second, those who identified with the worldview of shan books further publicized them by means of xuanjiang and often started grassroots organizations called Shiquanhui to promote shan actions, including salvation of the poor. In other words, the moral standards of shan books were not only internalized at the individual level; because the shan worldview also meant to expand the scope of shan influence to other people, these moral standards were internalized at the societal level as well.

The Liaofan School described in Fucheng Qixin is a way of thinking started and spread by Yan Liaofan at the end of Ming Period to encourage shan based on Gongguoge. Gongguoge categorized human actions into good and bad conduct, defined them in detail, and quantified the number of good and bad acts to serve as an indicator to encourage the accumulation of shan. Followers believed that if one amasses points of shan by doing more good, he or his descendents would eventually be rewarded. For example, Guangxu "Jintangxian Xiangtuzhi," Volume II, cites examples of people who devoted themselves to leshan haoshi (enjoying goods and delighted to give), including establishing public cemeteries, preparing coffins, providing warehouses, saving people in disasters, providing military training, and taking care of orphans and widows. It concludes their biographies in a formulaic way by mentioning the prosperity of descendants, success in higher civil service examinations, and the obtainment of a bureaucratic position as rewards for the accumulation of shan, high morals, filial piety, and benevolence. It clearly shows that one's accumulation of good acts will serve as a cause for personal reward or reward for one's descendants.

The first trigger driving people toward the act of shan was the law of causeand-effect, as people wish good luck for themselves and their descendants. However, that was not the only reason that prompted people to identify with shan. The second trigger was related to the story of jie and shan, the catastrophe the world was facing and the means for saving the world. Although the acts of shan by local people with high morals described above might seem unrelated to the idea of avoiding jie, its elements can be clearly observed in the Shiquanhui organized by Zhang Deshen and Cha Shunbang in chang (town). The relatively detailed introduction of Shiquanhui can be found in the Republic of China, Nanchuanxianzhi, and the Republic of China Daxianzhi.

These years, many philanthropists in our prefecture have started organizations of Shiquanhui .... Their purpose is to raise contributions from many people and practice charity with them .... This organization started in the 5 th year of

(Kokusho Kankokai, 1999). Zian Yu, Quahuaanzhen: Qingdai Quanshanshu Yanjiu (Tianjin People's Publishing House, 1999). 
Tongzhi in the Qing Period when Guanshengdijun (saintly emperor Guan) gave divine guidance through Fuji in Wulingshan in Da Prefecture. In the 9th year of the Republic of China, God made a divine prophecy in dreams to spread its teaching in the northeast regions of Sichuan. All of the rules of this association are based on divine guidance. According to divine guidance, the people of Sichuan should face ten jie because they have committed ten bad deeds. However, Shidashensheng (ten holy spirits) who descended to the world took pity on them and said they would obtain ten clues for salvation and realize ten virtues if they plan and practice ten kinds of shan. ${ }^{11}$

The 6th year of the Republic of China .... Everybody believes that jie cannot be avoided unless they practice ten public shan as they live in troubled times and disasters strike often. Therefore, people have resolved to start Shiquanhui. ${ }^{12}$

The origin of Shiquanhui was divine guidance given through Fuji. The detail of the guidance is not clear, but it should be noted that their activities were underpinned by the belief that Shiquanhui should practice shan to avoid jie in Sichuan local societies before and after the Xinhai Revolution. ${ }^{13}$ Also, it was very common to try to find the rationale of benevolence in divine guidance given by Fuji, just like the start of Shiquanhui. Fucheng Qixin lamented the prevalence of Fuji, but reflected the actual situation of local societies. Below is an example of the practice of shan based on guidance provided by Fuji.

The Taipin Rebellion broke out in Daoguang Xianfeng Period, followed by the Nien Rebellion in Henan. Also, the Hui and Miao Rebellions took place in Yunnan and Guizhou, respectively. The world was full of unrest and people started to say that the world was on the verge of jie and that they would not be able to avoid disaster unless they practice shan. Therefore, spiritualisms such as Fuji and Feiluan became very popular. There was no village school in Baishachang at that time. One Fuji revelation instructed people to found a school. Du Baotian heard of this and renovated the Longmen local school, which had been built in the past by

\footnotetext{
11 The Republic of China, Nanchuanxianzhi, Volume 10, Gongshan.

12 The Republic of China, Daxianzhi, Volume 9, Lisu.

13 According to Sakurako Komukai, "Shinmatsu Minshoki no Mintatsu Jizenkai to Jizenjigyo" [Minda Cishanhui and Charities in the Late Qing Dynasty], in Ekkyosuru Kindai Higashi Ajia no Minshu Shukyo [Cross-Border Folk Religion in Modern East Asia], ed. Fusaji Takeuchi (Akashi Shoten, 2011), which discusses religious charity groups in Chongqing, Minda Cishanhui preached people to avoid jie with corrected minds and published a shan book titled, Guansheng Dijun Shiquan Shanben. The connection between the idea of avoiding jie, Guansheng Dijun's divine guidance, and Shiquan might be expected here as well.
} 
Gou Huan, a person from the village. ${ }^{14}$

As shown in the story of Du Baotian, shan was recognized not only as an important investment to bring luck to individuals and their descendants, but also as participation in saving the world from catastrophe. Although I do not discuss this point in detail in this article, as I have discussed it in previous research, many shan books that preached that practicing shan was the only way to avoid the jie resulting from the bad deeds of people were published because of divine guidance given by Fuji, especially in Sichuan. ${ }^{15}$ If a catastrophic disaster is bound to happen as punishment for bad deeds, the only way to avoid it is by doing good deeds, even if it takes a long time.

Shiquanhui was an organization founded mainly at the changzhen (town) level. ${ }^{16}$ Although people were supposed to practice ten kinds of shan, the details of these shan vary slightly from region to region. For example, even within Dazhu Prefecture, some people cited helping the poor and orphans, providing medication, helping those in danger, fighting for justice, providing clothing in cold weather, providing coffins, completing marriages, having moral integrity, providing tea, and burning lights as ten items, while others cited more than ten items, such as taking care of orphans and the elderly, creating a public cemetery, providing coffins, preaching, providing medication, providing porridge, providing clothing in cold weather, maintaining bridges and road, collecting waste paper, putting soil on old graves, cleaning lonely graves, providing lighting, providing the poor with travel fees, and providing braziers and ashes. ${ }^{17}$ Shigonghui in An Prefecture listed the following ten cishan (giving shan) items: nursing babies, helping widows, providing medicine, providing clothing, helping to tide over crop failures, gathering bones, preaching, cherishing literature, improving literacy, and saving lives. ${ }^{18}$

It is understandable that many items mentioned above are about providing financial support for those in difficult situations, but it is interesting that one

\footnotetext{
${ }^{14}$ The Republic of China, Hechuanxianzhi, Volume 48, Xiangxian.

15 There are numerous shan books with the idea of preventing jie published in the late Qing and early Republic periods. For example, "Sontokudo ban Doukyo Souten" [Zende Dang's Collection of Taoist Scriptures] at Ryukoku University, which is a collection of shan books published in Jiangbeiting, Sichuan Province, in the late Qing Dynasty, includes some sermons on the approach of jie and the dissolution of it by conforming to correct standards. See Akiko Tsuzuki, "Ryukoku Daigaku Omiya Toshokan Zou 'Sontokudo ban Doukyo Souten' Kaisetsu [Commentaries on "Zende Dang's Collection of Taoist Scriptures" at the Ryukoku University Omiya Library], Ryukokudaigaku Ronshu 461 (2003).

${ }^{16}$ In Sichuan, the word changzhen is often used to express market towns. This article refers to market towns as changzhen hereafter.

17 The Republic of China, Dazhuxianzhi, Volume 11, Cishan.

18 The Republic of China, Anxianzhi, Volume 13, Jianzhi.
} 
of the good deeds is xuanjiang (preaching). Recall that Cha Shunbang from Hechuan Prefecture was preaching shan with citations from Ganyingpian and Yinzhiwen. As mentioned above, a huge amount of shan was required to offset the long accumulated bad deeds and avoid jie. Therefore, shan was expected to be shared by many people as "public shan" instead of as a means only to realize the happiness of individuals and their descendants. This is why spreading shan to others by various means, including xuanjiang, shan books, talks, performances, and letters was also perceived as an important act of shan. The following is a wellknown example of xuanjiang in Sichuan local societies. ${ }^{19}$

A teacher who gives lectures on "holy guidance" often came to my village and explained about shan books on loyalty, filial piety, fidelity, and moral obligation. Many shan books were about local legends .... At the entrance of the town, there was a high stand made of three square desks with one square desk placed on the middle of the other two desks. Incense sticks and candles were put on the stand next to the tablet of "holy guidance" .... The teacher, who lectured on "holy guidance" dressed in his ceremonial robes for the lectures, kowtowed to the tablet of "holy guidance" four times, stood up and read ten articles of "holy guidance" with a drawling voice. Then he sat down again to start lecturing about the books.

According to the childhood recollections of Guo Moruo, xuanjiang was actually used as an opportunity to "lecture about shan books on loyalty, filial piety, fidelity, and justice" under the guise of holy guidance. A local chronicle during the Republic of China wrote, "Rich families eager to practice shan host xuanjiang by hiring xuanjiangsheng (xuanjiang lecturer). They place high stages on the street and put tablets with words of holy guidance on the stages." ${ }^{20}$ This illustrates that xuanjiang was held on high stages in the town like for preaching and hosted by rich local philanthropists. Cha Shunbang, described above, exactly represented one of these "rich families eager to practice shan."

Sometimes divine guidance was given during xuanjiang. Niu Shumei, who was a magistrate of Zizhou during the Daoguang Period, heard about such cases and said once said as follows:

\footnotetext{
${ }^{19}$ Moruo Guo, Wode Tongnian [My Childhood] (People's Literature Publishing House, 1992). This article refers to Shinobu Ono and Noboru Maruyama, trans., Watashino Youshonen Jidai (Heibonsha, 1967). Also, Rutan of Liaoping Prefecture in Sichuan Province, reported in Yi Yu, "Sichuan Liaoping 'Rujiao' Zhi Kaocha" [Consideration on Confucianism in Lioaping, Sichuan], Minjian Zongjiao, Volume II (Nantian Shuju, 1996), can be considered a form of xuanjiang.

${ }^{20}$ The Republic of China, Qianweixianzhi, Volume 7, Wenshi.
} 
When I was governing Zizhou, I went to the countryside on official business and spent a night at a study house. One student approached me and said, "We are seeing the effects of lectures on holy guidance in our village." I asked him what he meant ... and he said, "The other day, right after a lecture of holy guidance, Guanshengdijun descended to the xuanjiang altar. The teacher of my academy was there, and kneeled down to ask several questions. We got answers for every question, and Guanshengdijun wrote numbers to the teachers in bit characters. After a while, Huanhou (Zhang Fei) also descended. His qi was fierce and completely different from that of Guanshengdijun." I was skeptical of the story told by the student and asked him whether it was Fuji. He replied, "No, a twelve year-old student was possessed by him.",

Zhong Tizhi, who heard this story from Niu Shumei, stated that a boy was possessed by the supernatural in Xiehong Prefecture, "swinging his hair and wielding a sword," and that the divine guidance given there was published as a book, Wanhui Tinxin Ji (Recovering the Heart of God)." He described that people were enthusiastic about it as if "all people in the country were crazy." The name of this book seems to imply that the disaster of jie can be recovered by doing things that please the heart of God.

\section{The 1911 Revolution in Panshi Village, Da Prefecture}

While the previous section described the orientation of shan, this section will focus on a specific region and discuss the transition of shan during the Revolution. The region is Panshi Village in Da Prefecture. Local elites in Panshi Village promptly reacted when the 1911 Revolution broke out. Local society around that time was to some extent illustrated in Daxian Panshixiangzhi (The chronicle of Panshi Village, Da Prefecture).

Daxian Panshixiangzhi was a chronicle of the local village compiled in $1943 .^{22}$ Although many "village chronicles" below prefectural-level were published, especially in the Jiangnan Delta, this is the only village-level chronicle known in Sichuan. Panshi Village was centered in the market town of Panshi, located at the intersection of $\mathrm{Da}$, Xuanhan, and Wanyuan Prefectures. It had been long governed by these three prefectures during the Qing Period. In 1935 it came under the

\footnotetext{
21 Tizhi Zhong, "Chongzhengchuxielun," in Caoxuetangwenchao, Volume 5.

22 Daxian Panshixiangzhi was published in 1943 and stored in the Sichuan Provincial Library and others. This article refers to the copy of Zhongguo Zhifangzhi Jicheng, Xiangzhenzhi Zhuanji 29 (Jiangsu Guji Press, 1992).
} 
jurisdiction of Da Prefecture through the annexation of areas and the demarcation of borders. The actual social unit within Panshi Village was consistent with the administrative boundary. This origin and history might be one of the reasons that a village chronicle, which was rare in Sichuan, was compiled here. In any case, this village left materials that can be used for discussion on social trends at the grassroots level.

In 1911, many movements broke out throughout Sichuan once people heard about the Wuchang Uprising. In Panshi Village, Li Runtang, Mou Xingruo, Xiao Yuanpu, Gao Dasan, Gao Diansan, Li Zhisan, Li Chengjiu, Liao Jingtang, Xiao Zuozhen and Tian Jinsan compacted at Panshi Wenchang Temple by drinking blood and departed for Xuanhan with several hundred people. However, the magistrate of Xuanhan Prefecture had already fled, so they headed to the capital of Da Prefecture with insurgent armies from various regions, led by a famous leader of Gelaohui, Li Shaoyi, whom they had met on the way. After encircling the capital for three days, Magistrate of the State and Prefecture, Du Bengchong and Guang Hou, respectively, fled, and Da Prefecture "declared its independence and was governed by the people of the prefecture." This is the account of local elites in Panshi Village and Da Prefecture. ${ }^{23}$

Among the ten people leading the movement in Panshi Village, Daxian Panshixiangzhi includes information about the lives and religions of the following eight after the 1911 Revolution: Li Runtang, Mou Xingruo, Xiao Yuanpu, Gao Dasan, Xiao Zuozhen, Tian Jinsan, Gao Diansan, and Li Zhisan, though the level of detail varies from person to person. ${ }^{24}$ The following is what is known about these eight people.

\section{(1) Li Runtang}

His father was Li Guangfa, who became a student of the highest educational institutional in the first year of Guangxu. "He was always passionate about shan ... therefore he was loved and respected in the village." His son's name was Runtang Yuyu. He joined Gelaohui in the late Qing Period, refurbished Tianbaosai (Tianbao Fortress) on top of a rocky hill next to Panshi for use as a camp, led local soldiers, and defended Panshi Village. Like his father, he was devoted to shan, and "supported justice at all times and despised evil as an archenemy. He led the

\footnotetext{
${ }^{23}$ Daxian Panshixiangzhi, Volume IV, Zajimen, Dashiji.

${ }^{24}$ Daxian Panshixiangzhi includes the biographies of these eight people and their relatives: Li Guangfa (father of Li Runtang), Volume IV, Xueshenmen, Wenwukedi; Li Runtang, Volume IV, Renwumenshang, Xiangxian; Mou Xingruo, Volume IV, Xuexiaomen, Wenwukedi; Xiao Yuanbo, Volume IV, Renwumenshang, Xiangxian; Gao Dasan, Volume IV, Renwumenshang, Fangji; Gao Zhao (mother of Gao Dasan), Volume IV, Renwumenxia, Cishan; Xiao Zuochen, Volume IV, Xuexiaomen, Wenwukedi; Tian Yutang (from the same family as Tian Jinsan) Volume IV, Xuexiaomen, Xiancunrenshi.
} 
restoration of xuanjiang, the promotion of lianzong (combined branches of clan), and the maintenance of bridges and roads for every occasion without exception." It was written that he was 65 years old in 1941, which means he was 35 years-old during the 1911 Revolution.

\section{(2) Mou Xingruo}

He had been a low-ranking official in the government office in Xuanhan Prefecture, and was active in "local public affairs" after retirement in his later years. He died at 68 years-old in 1931. It is not rare to find that members of powerful Chinese clans had worked as low-ranking officials in East Sichuan. It is fair to say that they sought opportunities to climb the ladder and get closer to power, and became part of the prefectural government in various forms, such as by passing the imperial examination or the military imperial examination, obtaining low-ranking official positions, and buying the positions of government officers.

\section{(3) Xiao Yuanpu}

He contributed to the local militia by serving as the leader of a tuanwu (local militia) in Da Prefecture in the early years of the Republic. Also, he constructed an ancestral hall for his family and called for lianzong. He died at 50 years-old in 1929. His oldest son, Xiao Xinping, was known as jigonghaoyi (public-spirited and kind-hearted) and held several positions, including principal of Panshi Central Elementary School.

\section{(4) Xiao Zuozhen}

He served as a prefectural assembly member and leader of the Xiao family. He died in the first year of the Republic.

\section{(5) Gao Dasan}

His ancestor, Gao Tingyuan, was recommended as leader of Tianbao Fortress during the uprising of Lan Dashun. Gao Dasan ran a pharmacy but charged little money from the poor. His mother, Gao Zhao, was leader of Shengxue Xuanjiangtan Nujushi (women's association of holy study preaching). Also, he was an "advisor," together with Li Runtang, in the compilation of Daxian Panshixiangzhi.

\section{(6) Tian Jinsan}

His name is not found in biographies, so details are not known. As a head of the schools, he restructured village schools into the Panshichang Public Elementary Schools and served as leader of the Da Prefecture local militia. He also constructed a family tree of the Tian family. Tian Family Tree, written by Tian 
Jinsan and quoted in Daxian Panshixiangzhi, ${ }^{25}$ shows that the family included Tian Yutang and his son Tian Yonghong, whi joined the local militia.

\section{(7) Gao Dianxan}

There is no biography of Gao Diansan or of anyone who can be identified as his family. However, Benxiang Minguoshilijie Difangshourenbiao ${ }^{26}$ shows that Gao Diansan served as head of the cluster service bureau in Xuanhan Prefecture in the early 1920s.

\section{(8) Li Zhisan}

There is no biography of Li Zhisan or of anyone who can be identified as his family. Like Gao Diansan, he served as head of the cluster service bureau in Da Prefecture and, according to Benxiang Minguoshilijie Difangshourenbiao, assistant head under Xiao Yuanpu in the early years of the Republic.

From these biographies it can be known that many tried to protect local societies as leaders of the local militia during the unquiet days before and after the Xinhai Revolution, educated people by holding xuanjiang, founded schools and assembled families together, and made efforts to construct and maintain desirable order through edification. Among these activities, their involvement in xuanjiang should be especially noted. As stated in the memoirs of Guo Moruo, xuanjiang was originally an act to gather people on a regular basis and read out Article 16 of the holy guidance given by the Kangxi Emperor. However, these readings transformed into lectures on shan books held in changzhen to preach popular morals in a plain style. As mentioned above, promoting xuanjiang was itself recognized as an act of shan.

Daxian Panshixiangzhi mentions the subject of xuanjianghui (xuanjiang sessions) and provides a detailed description of their origin and its popularity in the following years. ${ }^{27}$ According to this description, a man in the late Qing Period named Li Hepu, in Liangzipu, Da Prefecture, entered a prefectural school but gave up on personal aggrandizement and fame later in life. Hoping to edify people and save the world, he traveled to nearby cities to preach to men and women, correct bad deeds with good deeds, and avoid jie. Men pledged to God to maintain the Six Commandments proclaimed by Guanshengdijun: do not neglect filial piety, do not disrespect older brothers, do not have affairs with women, do not gamble, do not kill, and do not be involved with evil. Women pledged to God to maintain the Six Commandments proclaimed by Zaojun: do not neglect filial piety, do not

\footnotetext{
25 Volume II, Lisumen, Zupu.

${ }^{26}$ Volume I, Guanshengmen, Mizhi.

27 Volume II, Lixumen, Fengsu.
} 
disrespect Zaojun or your husband, do not neglect sisters-in-law, do not have abortions and do not drown newborn baby girls, do not waste food, do not primp, and do not neglect your studies. These activities by Li Hepu triggered people to hold numerous xuanjiangtan (preaching platforms) in areas near Panshi. In the early years of the Republic, Peidetan and Chongshantan were started in various areas within the village, and Tianyoutan was started in the Panshi Hall of the Emperor in 1918. It can be inferred from the names of these xuanjiang sessions (with tan at the end) that divine guidance might have been given through Fuji or possession. After these sessions died out over the next few years, more than one-hundred people, including Li Runtang, once again started Zhiyouyue and Shiquanhuiin the Hall of the Emperor. In 1936, the Panshi Shengxue Xuanjianghui (Panshi Holy Study Xuanjiang Association) was founded with Li Runtang serving as head of Zhiyouhui.

It should be noted that these people preached that the objective of xuanjiang was to "correct bad deeds with good deeds to immediately avoid jie." ${ }^{28}$ The idea that the world was facing a catastrophic crisis as a result of accumulated bad deeds by human beings was surely accepted in Panshi Village. The only way to avoid jie was through Shiquanhui, and people worked on reforming characters and practiced shan in order to gradually purify the world. It should also be noted that the Six Commandments of Zaojun was cited as the daily norms that women should follow. Zaowangfujun Nuzi Liujie (Zaojun's Six Commandments for Women), which has almost the same contents except for some Chinese characters, is cited at the end of a shan book titled, Wushengxuexinwen, which is said to have been completed in Sichuan in the late Qing Period. ${ }^{29}$ This book encouraged readers to "recover God's will" by repenting wrongdoings and practicing shan, such as xuanjiang, based on the divine guidance of Guanshengdijun, in order to save people from the jie about to occur in Sichuan. It is possible to guess that Shiquanhui, xuanjiang sessions in Panshi Village, also shared the ideas of shan and jie.

In 1914, a few years after the Xinhai Revolution, Xiao Yuanpu and ten other people, including Li Runtang, Mou Xingruo, Li Zhisan, Xiao Zuozhen, and Tian Jinsan, requested the magistrate of Da Prefecture to ban fishing with the use of poison in two locations of a river in the village, Xiongshidong and Liuwangtan.

\footnotetext{
${ }^{28}$ Gaiexiangshan, Sutaodajie.

${ }^{29}$ Wushengxuexinwen is included in the above mentioned "Sontokudo ban DokyoSouten" at Ryukoku University. It was said to be obtained through Fuji in 1860, as it says, "The guidance was given in the year of Gengshen." There are the following three differences between Zaojun's Six Commandments and Daxian Panshixiangzhi: Jiebuxiao Gongpo Fumu became Jiebuiao Fumu Gongpo, Jiebuhe Zhouli became Jiebuhe Jiemei Zhouli, and Jie Yanzhuang Feizi became Jie Yanzhuang (zhuang with a different Chinese character, feizi.
} 
This request was accepted and the ban was issued. The following sentences show the interesting thoughts of the local elites who called for the ban.

This is decided based on the request of Xiao Yuanpu, a division head of the cluster service bureau of Panshi, and others. Tradition says that if people pray for rain during a drought in these two areas, Songshidong and Liuwangtan in Panshi, a miracle will happen. As there are a lot of fish in those areas, fishermen and peasants living near the river catch fish with fishing poles or by casting nets. These days, some even put poison in the river. With this method, millions of fish can be caught at one time. However, conflicts are taking place due to unfair allocation of the fish. The drought this summer was more severe than past droughts. This might be a divine punishment because many people are catching fish with poison and not oriented to shan .... Catching fish with poison is against a love of shengxian (the holy and the wise) for living creatures. The leaders of the village prayed for rain several times to no avail, so people had discussions to address the situation. Nobody is allowed to throw poison to catch fish at the riverside areas from Songshidong to Liuwangtan. With this we might be able to recover God's will and bring clouds that give us rain. ${ }^{30}$

Among ten local elites from Panshi Village who made a compact upon the Xinhai Revolution, six people were involved in this ban issued in 1914. Although the ban was about the use of poison in fishing, the logic behind it should be noted. In areas near Songshidong and Liuwangtan, people had held ceremonies to pray for rain in dry summers since the Qing Period, but their prayer had lost its effectiveness. They thought that it was a divine punishment because they were "not oriented to shan" and unselectively killed living creatures with poison. Therefore, they needed to ban such bad practices in order to "recover the will of God."

From today's perspective, throwing poison into the river is not favorable since it would contaminate the water system and harm human health. However, people in this time period saw it as a breach of the norms of shan, which required them to respect lives. For example, in the biography of Fan Shaowen, included in Jintangxian Xaingtuzhi, Qijiulu wrote, "He was devoted to practice shan his whole life. When the mountain streams were dry and fishes and shrimps were suffering, he always had people move them into the river". This implies that protecting and nurturing the lives of living creatures other than human beings was also considered shan. It should be remembered that "saving lives" was mentioned as one of the acts of shan to be practiced by Shigonghui in An Prefecture. Although the importance and urgency may vary, the idea of shan is not limited to

${ }^{30}$ Daxian Panshixiangzhi, Volume I, Jianzhimen, Guji. 
saving people by nurturing babies and taking care of orphans and widows, but its ultimate goal is to maintain the order of the whole world in a harmonious manner by showing compassion to all living creatures facing hardship. Under this concept of shan, everything in the world was perceived to be connected, and people believed that all acts of human beings, no matter how small, could affect the destiny of the world. Drought was thought to be a divine punishment for harming numerous lives and the prayer for rain did not work anymore. It was essential to start practicing shan, or at least stop wrongdoings, in order to rectify this. The poison ban was imposed by leaders with a shan worldview and supported by those who took such a narrative for granted.

The aspiration for "traditional" shan and the trend of the "new" revolution were not in opposition, at least in Panshi Village in Da Prefecture. Rather, local elites who were passionate about shan led local society before and after the 1911 Revolution. For local elites in Panshi Village in Da Prefecture, the ethic of shan did not contradict with their participation in the Revolution.

\section{Independent Local Societies:" Shan" and the Revolution}

In local chronicles completed in the period of the Republic, the 1911 Revolution is often described as an "independence" movement. As mentioned earlier, after municipal government officials dispatched by the Qing Government fled when the capital of Da Prefecture was surrounded by Li Runtang and others from Panshi Village, the prefecture came to be "governed by the people of the prefecture and independence was declared." This was the actual circumstance during the revolution. In other words, when viewing the revolution in the mountain areas of northeast Sichuan Province, what is seen is not a story of a transformation of the central or entire political system as a whole, but individual stories of prefectures gaining independence from or breaking away from the governance of the Qing Dynasty. As such, it is necessary to determine what kind of social structure, beliefs, and thoughts generated these ideas of autonomy and independence.

When discussing the mountain areas of northeast Sichuan Province, it should be noted that the local societies had accepted a large number of immigrants until the Mid-Qing Period. This means that these societies started as immigrant societies that experienced a rapid population increase from the seventeenth to the eighteenth century. The inflow of immigrants would have naturally led to a dramatic increase in residential population, including temporary residents. The expansion of residential areas would have required the development of untapped lands deep in the mountains. Social problems requiring action by the local administration must 
have grown as a result. However, the small dynasty of traditional China floating above society did not have the ability to promptly deal with this expansion and adjust the fiscal scale of local governments. Also, under the rule of virtue subjects are naturally led to the ideal order when they become influenced, so intervention in the affairs of local governance was something to be avoided. Therefore, local societies that accepted immigrants were dealt with in a laissez-faire manner and continued to expand despite their internal conflicts and tensions. Moreover, local societies saw the public administration of the Qing Dynasty as shrinking and distancing itself from them. ${ }^{31}$

Against this backdrop, a parastatal organization called gongju (public bureau) was established to facilitate increasing local administrative affairs and maintain local order. In Hechuan Province the first gongju was started in $1834 .{ }^{32}$ Fourteen xushen (local elites) delegated by the local government then started Liuzhengju (Six Affairs Bureau) to implement six types of welfare services, including nurturing babies, sponsoring higher civil service examinations, taking care of widows, supporting the poor living near rivers, accommodating refugees, and taking care of the dead and providing coffins, in order to address social issues in the area and maintain order. It can be observed that the services provided by Liuzhengju are almost the same as those carried out by local elites to represent shan through organizations such as Shiquanhui. In other words, voluntary charitable activities by Shiquanhui and others were spreading at the changzhen level below gongju, which was organized at the prefectural-level. It can be said that the method of gongju led by the government penetrated down to grassroots societies. Alternatively, it can be said that a semiofficial organization called gongju was a tip that emerged in the surface of the ocean filled with a passion for shan in grassroots societies. In either case, these two bodies did not exist separately and it should be assumed that they were seamless from the beginning. This means that charitable activities of Shiquanhui and others observed at the changzhen level were nothing short of local elites' voluntary acts to maintain social order in local societies, and they regarded it as a challenge they should address.

Local societies' ability to autonomously maintain order developed structurally as they expanded and the capacity of the Qing Dynasty to govern concurrently

\footnotetext{
${ }^{31}$ As for the situations of societies and local elites in the late Qing dynasty, see Yamada, Ijumin no Chitsujo. Yujiro Murata, "Chugoku Kindai Kakumei to Jukyo Shakai no Hanten" [The Transformation of Confucius Society and the Modern Chinese Revolution], in Chugokutoiu Shiza [Viewpoint Called China] ed. Yuzo Mizoguchi, Takayuki Ito, and Yujiro Murata (Heibonsha, 1995). J. W. Esherick, and M. B. Rankin, eds. Chinese Local Elites and Patterns of Dominance (University of California Press, 1990).

32 As for Liuzhengju, see Yamada, Ijumin no Chitsujo, Chapter 6: "Shisensho Goushu Koukyoku: Shinryo Taisei no Seiritsu [Hezhou, Sichuan Province: the Establishment of Gongju, Shenliang System].
} 
shrank. This trend was accelerated by the political confusion at the end of the Qing Dynasty. Although national governance was withdrawing, local elites had to rely on the Qing Dynasty's power as long as its authority was not fundamentally doubted. However, when the Dynasty's authority and power dissolved, local societies had no choice but to protect their autonomy and independence by proactively forming local militias. By this time the trend of local independence had become more prominent. Also, the Railway Protection Movement in Sichuan, which served as an important trigger of the 1911 Revolution, can be considered a local society's reaction to power, as governors and officials from the Qing Dynasty intended to control local governance through the nationalization of railways despite having enabled the independence of local societies.

Independence needed to be acquired not only from the Qing Dynasty but also from the Dynasty's local authorities. Local elites were seen as at the top of the social hierarchy, but this status was based on recognition by the local government or the civil service examination, which was centrally managed by the Qing Dynasty. When the supply line of authority from the Qing Dynasty stopped functioning, local elites had to legitimize themselves through a means from within the local society. This means was the guidance given by the God through Fuji and spiritualism, which guaranteed their right as leaders. The shan of local elites was nothing more than saving people in poverty and maintaining order based on ethics, such as loyalty, filial piety, fidelity, and moral obligation. Nevertheless, this ordinary, conventional ethic was presented by God as the code of conduct to save local societies amid the crisis of the dissolution of the entire order, which was interpreted as jie.

Two aspects of this situation require further consideration. The first is the authority of local elites in times of crisis and during independence. In the dissolution of the entire order, local elites had no choice but to find a source of power and authority to stand on. They tried to maintain local order through a traditional ethic by organizing armed forces with local militias while being grounded on divine guidance. In this circumstance, the ethic of independence acquired through direct talk with God was forced by the crisis; it was created by fantasy through an urgency to leap to a solid justification for rightness in a time when the world was "full of unrest" and "all people in the country were crazy."

The second is the relation between shan and the revolution. Based on the above interpretation, it is understandable why local elites obsessed with shan "made a compact by drinking blood" and acted for the independence of Da Prefecture. Because the power of the Qing Dynasty had become a barrier preventing local elites from realizing righteousness, local societies needed to become independent by eliminating the Dynasty's control. Because the ideal, right order was preserved 
in local societies, and "a country is an aggregation of villages," 33 the entire order of the nation had to be shaped as a result of the aggregation of small units of local societies. Shan and the passion for the revolution did not conflict as long as their basic ideas were to reconstruct the entire order through grassroots independence, which was the level of society where shan was realized. ${ }^{34}$

\section{Conclusion}

The "old" worldview since the end of the Qing Dynasty based on shan brought by Fuji and spiritualism did not axiomatically conflict with the "new" ideas from the Revolution in Sichuan local societies. Rather, they might have been two sides of the same coin of independence.

Nevertheless, local elites who advocated the "old" world view described in this article were not the only advocates who had influence in local societies. When the Qing Dynasty, a huge source of power and authority, was nearly dissolved, there may have been several advocates who created social trends by acquiring followers and competed for legitimacy. In other words, it is possible that people fought for legitimacy and the legitimacy of local elites who dominantly represented shan must have been constantly challenged by private religious associations also authorized by Fuji and spiritualism and local elites who sympathized with the authority of sophisticated modern intelligence, such as the editors of Fucheng Qixin. ${ }^{35}$ The local elites who acted as representatives of traditional shan could have been attacked by both parties at any time. This means the authority of local elites who represented shan was not guaranteed. As such, this was the very reason local elites made continuous efforts to spread the word of God through Fuji and spiritualism and repeatedly publicized themselves through shan books and xuanjiang.

Lastly, I would like to confirm some points not discussed in this article. The first is regarding the name of the 1911 Revolution itself. A series of political unrest that started with the Railway Protection Movement in Sichuan and Wuchang Uprising was later named the 1911 Revolution. This name might invoke an image

\footnotetext{
${ }^{33}$ Daxian Panshixiangzhi, Xiaocong Zhunxu.

34 The idea of constructing the entire order from regions is mentioned in Masaru Yamada, “Chugoku Minchojidaishi Kenkyu ni Okeru 'Chiikishakairon' no Genjo to Kadai” [The Situation and Challenges of "Discussions on Regional Societies" in Studies of the Ming and Qing Periods in China], Rekishi Hyoron 580 (1998).

35 One example of such private religions was Hong Deng Jiao, which was widely observed in Sichuan in the late Qing and early Republic periods. Their movement was to punish "the corruption of government officials, local tyrants, and evil gentries" by being possessed by God. See Yamada, Ijumin no Chitsujo, Chapter 7: "Shinmatsu Shisenno Koutoukyo Hanran" [Rebellion of Hongdengjiao in Sichuan in the Late Qing Period].
} 
of a large narrative in which the Xinhai Revolution brought a critical change in all of Chinese society. However, Daxian Panshixiangzhi only states that "autonomy" and "independence" were acquired by the people in the prefecture when the era name was changed to the Republic in retrospect. Of course, village chronicles are expected to focus on local history, so they did not actively comment on the whole nation. However, it should be noted that the name "1911 Revolution" was not mentioned even once in the chronicle as far as I could see. Given this, it is important to consider how political changes in 1911 were recognized in local societies of Sichuan Province, which was one of the epicenters of the 1911 Revolution due to the Railway Protection Movement. In other words, there are some issues to be discussed about the 1911 Revolution from the perspective of rural societies far from urban centers.

The second point is the ultimate impact of the pursuance of shan. This article focuses on shan as a symbolic resource for local elites to secure legitimacy in changzhen-level societies. Therefore, I did not discuss the possibility that their worldview continued to exist as the underflow of Chinese modern history and served as an ideological driving force for social reforms. I have considered this point in a separate article, but the idea that each individual has to reform and practice shan in order to save the contaminated world under the assumption that the world is facing jie has an affinity for the revolution worldview, which intends to completely transform the existing social system. ${ }^{36}$ Also, the idea of restoring the entire order by accumulating local societies backed up by an ethical community has an affinity with the methodologies of nation building in Chinese modern history, such as interprovincial autonomy. Careful considerations are required when discussing these topics, but it is probable that the underflow did not end but continued to transform into several "new" worldviews in a phased manner. These issues should be discussed separately in future research.

\section{Bibliography}

Esherick, J. W., and M. B. Rankin, eds. Chinese Local Elites and Patterns of Dominance. University of California Press, 1990.

Fujiya, Koetsu. "1906 Nen no Ping Liuli Houki to Minshu Bunka-Chuushusetsu no Yougen wo Chushinni" [Popular Culture and the Ping Liuli Uprising in 1906: On Popular Songs of Zhongxiujie]. Shigaku Zasshi 113, no. 10 (2004).

Fujiya, Koetsu. "Shingaikakumei no Shinsei: Konansho no Minshu Bunka wo

36 This outlook is stated in Yamada, "Kakumei Ideorogii no Tooi Suimyaku." 
Chushin ni" [Mentality of the Xinhai Revolution: On Popular Culture in Hunan Province]. In Chukasekai to Kindai (Series 20 Seiki Chugokushi 1), edited by Wataru Iijima, Tooru Kubo, and Yujiro Murata. University of Tokyo Press, 2009.

Guo, Moruo. Wode Tongnian [My Childhood]. People's Literature Publishing House, 1992.

Komukai, Sakurako. "Shinmatsu Minshoki no Mintatsu Jizenkai to Jizenjigyo" [Minda Cishanhui and Charities in the Late Qing Dynasty]. In Ekkyosuru Kindai Higashi Ajia no Minshu Shukyo [Cross-Border Folk Religion in Modern East Asia], edited by Fusaji Takeuchi. Akashi Shoten, 2011.

Sakai, Tadao. "Chugoku Zensho no Kenkyu" [Studies on Chinese Shan Books]. In The Collection of Tadao Sakai Works, Volumes I and II. Kokusho Kankokai, 1999.

Sato, Yoshifumi. "Kindai Chugoku no Chihoshi ni Miru Kyodoishiki: Konan Chiho wo Chushinni" [Village Identity Observed in Local Chronicles of Modern China - Mainly in Jiangnan Province]. Shicho 56 (2004).

Takeuchi, Fusaji, ed. Ekkyosuru Kindai Higashi Ajia no Minshu Shukyo [CrossBorder Folk Religion in Modern East Asia]. Akashi Shoten, 2011.

Takeuchi, Fusaji. "Shinmatsu Shisen no Shukyo Undo: Furan, Senkogata Shukyo Kesshano Tanjo" [Religious Movements in Sichuan in the Late Qing Dynasty: Foundations of Fuji and Xuanjiang Style Religious Associations]. Gakushuin Daigaku Bungakubu Kenkyu Nenpo 37 (1994).

Tsuzuki, Akiko "Ryukoku Daigaku Omiya Toshokan Zou 'Sontokudo ban Doukyo Souten' Kaisetsu” [Commentaries on “Zende Dang's Collection of Taoist Scriptures" at the Ryukoku University Omiya Library]. Ryukokudaigaku Ronshu 461 (2003).

Yamada, Masaru. Ijumin no Chitsujo: Shindai Shisen Chiikishakaishi Kenkyu [Order of Immigrants: Studies on Sichuan Local Societies during the Qing Dynasty]. University of Nagoya Press, 1995.

Yamada, Masaru. 'Kiokusareru 'Chiiki': Ding Zhitan 'Shiinsai Shohitsu' no Sekai” [Remembered "Territory”: The World of Ding Zhitan's "Shi Yin Zhai She Bi"]. Toyoshi Kenkyu 62, no. 2 (2003).

Yamada, Masaru. 'Kakumei Ideorogii no Tooi Suimyaku: Shinmatsu no 'Kyugo' Shiso wo Megutte" [Water Vein of the Ideology of Revolution: About the Philosophy of Saving "Jie" at the End of the Qing Dynasty]. Chugoku-Shakaito Bunka 26 (2011).

Yu, Zian. Quahuaanzhen: Qingdai Quanshanshu Yanjiu. Tianjin People's Publishing House, 1999. 


\section{About the Author}

Masaru YAMADA is Professor of Faculty of Letters at Chiba University. He received his Ph.D. in Literature from Nagoya University. His research interests include Chinese local society under the Qing Dynasty, the history of Chinese folk religion, and comparative social history. His main publications include Ijumin No Chitsujo [Immigrant Society under the Qing Dynasty] (Nagoya, Nagoya University Press, 1995), Chugoku No Himitsukessha [Chinese Secret Society] (Tokyo, Kodansha, 1998).

E-mail: yamada@1.chiba.u.ac.jp 